DOI https://doi.org/10.18551/rjoas.2020-09.16

\title{
THE CORRELATION OF PRODUCTION COST WITH SELLING PRICE OF NATURAL SPECIALTY COFFEE AT PT. INDO CAFCO KABUPATEN ACEH TENGAH
}

\author{
IIma Fitri ${ }^{\star}$, Eliyin, Fita Ridhana, Askura Nikma, Karya Idris Abu \\ Study Program of Agribusiness, Faculty of Agriculture, University of GajahPutih, Indonesia \\ *E-mail: araemafitri@gmail.com
}

\begin{abstract}
PT. Indo Cafco is of the company that run in agribusiness field, especially in producing coffee such as full washed, honey and natural. Specialty coffee is produced in the special area, special process, special men, and produce special physic and taste, commercial in special place and having being parced in special amount and the special market. The natural coffee that ready to be launched, the price is decided by the marketing that is influenced by the goal of company to earn the profit and external factor such as demanding and market competition. The objectives of this study is to know the how much the production cost is and the correlation between production cost and sell cost of Natural Coffee at PT. Indo Cafco, by using correlation analysis Product Moment. The findings of this study is the sum of the production cost in producing the rough material is $12.545,9 \mathrm{Kg}$ become green bean $176,5 \mathrm{~kg}$ is about Rp.197.354.959,93,- with the average cost each kilogram is Rp.23.978.04,-The average selling cost of natural specialty coffee at PT. Indo Cafco is Rp.139.524,--. Output Correlation shows the significant level at 0,000 . Because of the level of significant coefficient between production cost and selling cost declare positive. The farmers are hoped sell the red cherry of coffee that is really ripe; therefore, the production of natural specialty coffee could have been improved. PT. Indo Cafco can increase the cost of natural specialty coffee with consideration of production cost came out. In addition, the researcher can re-study about the influencing factors of selling cost of natural specialty coffee at di PT. Indo Cafco or others company in district Aceh Tengah.
\end{abstract}

\section{KEY WORDS}

Production cost, selling cost, natural specialty coffee.

Geographic indication defines as the clue from the product resulted in influence of its geographic environment, either natural factor, men factor, or the combination of both, that give characteristics and the special quality of certain product (MPKG: 2009).

Coffee is one of national plantation commodity that holds the important role in the Indonesia economy. In general, there are two kinds of coffee bean; those are Arabica (the best quality) and Robusta. Arabica coffee is cultivated at the first time in Indonesia in 1696. Arabica coffee has a lot of varieties, depends on the country, climate, and the land ploughed where coffee is planned. This coffee has the good scent resemble with the mixture of fruit and flowers. It grows well at cold and fresh land. Arabica coffee also has the taste of acid that is not possessed by Robusta and has thick taste when it comes to the mouth (Haryanto, B. 2012).

One of Arabica producers in Indonesia is district Aceh Tengah. It has 14 sub-districts and geographically it placed between $200 \mathrm{~s} / \mathrm{d} 2.600$ meter above the sea level. Most of the land is placed between $1.000-1.600$ meter above the sea level, most of the coffee farm is on $1.200-1.600$ meter above the sea level that is the ideal place for Arabica coffee. Beside the good place, rainfall and the kind of soil at district Aceh Tengah is very proper for the Arabica coffee (Manurung: 2012).

Processing post harvest of coffee at district Aceh Tengah is done by wet process, wet milling (Wet Proses Wet Hull) or it is commonly called semi wash. The coffee bean is pulped that is flowed by water during the pulping to ease the process. Then ferment or curing for 8 hours to facilitate the washing process and remove attached mucus. Then the coffee is dried in the sun until the water content is between $35-40 \%$, doing of peeling of horn skin (hulling), 
Coffee beans that have their horns peeled are called pumpkin seeds. Pumpkin seeds sunbath again until the moisture content is $12 \%$, doing sort process until the bean become grade 1 or ready export (Fitri: 2020)

The average export volume of Indonesian Arabica coffee ranges from 52,500 tons per year. There are more than 50 export destinations for Indonesian coffee with the USA, Japan, Germany, Italy and the UK being the destination countries. The demand for Indonesian coffee from time to time keep increasing in considering that Arabica coffee produced by various regions of Indonesia has a taste character those are unique and excellent acidity, aroma, flavor. In addition, the level of domestic coffee consumption has reached $0.8 \mathrm{~kg} /$ capita / year (Yantu, M. R. 2010)

In the last 10 years, the coffee processing industry has increased due to the large number of market demands. Coffee that is exported must meet the quality standards set. Based on the Indonesian National Standard (SNI) in 2008, the exported coffee beans are Grade(quality) I. For grade I coffee beans need to be handled and processed beforehand from the original coffee beans (Nongrade) (Kementan.2012)

Processing is one of the most important things in post-harvest handling. One of them is processing random coffee into Grade I coffee beans, without proper postharvest processing there will be losses, (Miftah.2014)

PT. Indo Cafco is one of the company that processes coffee become full Wash, Natural and natural Pulp (Honey). For the processing of Specialty Coffee, it has been done on October 2019.

Table 1 - Production of Specialty Coffee at PT. Indo Cafco in October 2018 - September 2019

\begin{tabular}{lll}
\hline No & Name of product & Amount of production per year $(\mathrm{Kg})$ \\
\hline 1 & Full Wash Coffee & 5.224 \\
2 & Natural Coffee & 3.707 \\
3 & Honey Coffee & 1.195 \\
\hline Total & 10.126 \\
\hline
\end{tabular}

Source: PT. Indo Cafco (data primer processed).

Based on Table 1, amount of production Natural Coffee is $3.707 \mathrm{Kg}$. Natural is one type of post-harvest coffee processing that is carried out by dry processing it into green beans or ready for export. In particular, the natural processing of coffee cherries with the skin of the fruit still attached is sunbathed directly until the moisture content reaches $12 \%$.Natural Coffee tends to have a thicker body thickness and higher acidity, cleaner and uniform taste.

In Aceh Tengah, the price of Natural specialty coffee in the form of green bean coffee reaches IDR $150,000 / \mathrm{Kg}$. This is because the production process for specialty coffee takes a very long time and the production process is different from commercial coffee. Natural Coffee processing takes 30 days, the processing tends to take a long time because the coffee cherries that still have fruit skin contain a lot of water so they dry out for a long time. However, with dryhouse, it makes Natural Coffee drying out faster up to $15-20$ days. The existence of a dryhouse will certainly increase costs in the production process so that profits will decrease or even cause the company to experience losses.

Production costs that occur in processing finished products must be controlled so that there is no waste. Production cost control is needed so that production cost efficiency can be achieved so that optimal profit which is the main goal of the company can be obtained. Based on the above background, the authors are interested in conducting research with the title "The Correlation between Production Costs and the Selling Cost of Natural Specialty Coffee at PT. Indo Cafco".

Based on the above background, the identification of the problem in this study is: "is there a positive correlation between production costs and the selling price of Natural Specialty Coffee at PT. Indo Cafco?". 
The objectives of this study is to know the selling price and production costs and the correlation between production costs and the selling price of Natural Specialty Coffee at PT. Indo Cafco.

\section{METHODS OF RESEARCH}

The data used in this study are divided into two types, namely secondary data and primary data:

1. Secondary data to be used is in the form of time series data from October 2018 to September 2016, in the form of natural coffee selling price, cherry coffee purchase price, electricity costs, labor, building rent and packaging costs incurred in managing Natural Specialty coffee at PT. Indo Cafco;

2. The primary data used is the depreciation data for the equipment in Natural Specialty Coffee processing.

To determine the relationship between production costs and the selling price of Specialty Natural Coffee at PT. Indo CafCo, Aceh Tengah Regency, this study uses the Product Moment Correlation (Pearson) formula where variable $\mathrm{X}$ is the cost of production and variable $Y$ is the selling price, with the following formula: Sugiyono: 1999: 182).

$$
r_{x y}=\frac{n \sum X Y-\left(\sum X\right)\left(\sum Y\right)}{\left.\left.\sqrt{\left\{n \sum X^{2}-\left(\sum X\right)^{2}\right.}\right\} \sqrt{\left\{n \sum Y^{2}-\left(\sum Y\right)^{2}\right.}\right\}}
$$

Where: $\mathrm{X}=$ production cost $\mathrm{Y}=$ Selling Price; $\mathrm{r}_{\mathrm{xy}}=$ Coeficient Product moment correlation; $\mathrm{N}=$ Jumlah Number of observations (Production Costs and Sales Price of Specialty Coffee from October 2018 to September 2019).

$$
\begin{gathered}
\sum \mathrm{X}=\text { Total of Pruduction cost } \\
\sum \mathrm{Y}=\text { Total of selling price }
\end{gathered}
$$

Kuswadi (2005) also classifies costs based on cost behavior patterns, namely: Fixed costs and Variable costs. Kusnadi, (2000), costs are the amount measured in units of money, namely expenses in the form of transfer of wealth, capital stock expenditures, services rendered or obligations incurred. In general, the meaning of this cost is an inevitable sacrifice of economic resources to achieve certain goals (Prawirosontono, 2001).

Soerkawati Soerkawati (2002: 124) Said that production costs are usually classified into two, namely fixed costs: and variable costs. Fixed costs are generally defined as costs that are relatively fixed in number, and continue to be incurred even if the production obtained is a lot or a little. So variable costs are usually defined as costs that are influenced by the size of the production obtained.

Mulyadi (2005) Fixed costs whose amount remains constant are not influenced by changes in the volume of activities or activities up to a certain level of activity. Variable costs consist of the materials needed to obtain the output (Samuelson, 2003). Production costs are costs incurred to process raw materials into finished products that are ready for sale. The examples are the cost of machine depreciation, the cost of raw materials, the cost of supporting materials, the cost of salaries for employees who work in parts, either directly or indirectly related to the production process (Mulyadi, 2007).

Costs based on their nature are classified into two types, namely fixed costs and variable costs. Fixed costs are costs that are fixed, do not increase or decrease with a change in the number of products produced. For example, building rents will not increase if the number of goods produced will increase (Suwarto, dkk, 1997).

Sadono Sukirno (2004: 224).Fixed costs are costs spent that do not depend on the number of goods produced, costs do not change even though how much production is 
achieved. According to Sutriono (2006: 58), fixed costs are "costs that do not run out in the production process or capital that are not related to the amount of production produced and must be paid even if the plant does not produce.

Price is a very important part of marketing a product. Price is also one of the determinants of the success of a farming business because price determines how much profit will be obtained from selling the product (Suratiyah, 2008: 131).

Price is an important element in determining a company's income because income is the sum of nultiple between the price and the quantity sold (Hernanto, 2007: 152). Price is the amount of money that consumers have to pay to get the product. Price is the amount of money (plus some products if possible) needed to get the combination of goods and services (Assuari, 2008: 59).

\section{RESULTS AND DISCUSSION}

PT. Indo Cafco is a subsidiary of ECOM trading. Co. Ltd, based in Switzerland and America.In Indonesia, it has been established since 2001 in Lampung, and then in 2004 it has entered Medan. At the end of 2004 PT. Indo Cafco is expanding in Aceh to be precise in Takengon, which is located in Kampung Mongal, Bebesen Sub-district, Aceh Tengah Regency which is engaged in coffee processing. In 2005, opened another branch in Bener Meriah which is located in Pante Raya. Since 2015 PT. Indo Cafco has processed specialty coffee, i.e. full washed, honey, and natural then in 2017 specialty coffee has been processed at Pante Raya.PT. Indo Cafco is committed to promoting coffee cultivation, particularly in improving the quality, image and price of coffee in Indonesia. This is proven by conducting regular coaching for coffee farmers so that the opportunity to increase value increases for coffee farmers. Farmers are given training with good cultivation and processing patterns so as to produce quality coffee beans. With this activity, it is hoped that it can prosper and improve the economy of coffee farmers, especially those in Aceh Tengah district.

In developing its business, PT. Indo Cafco started to produce specialty coffee including Natural types or Natural Specialty Coffee, which began to produce in 2019. The following is the organizational structure of PT. Indo Cafco:

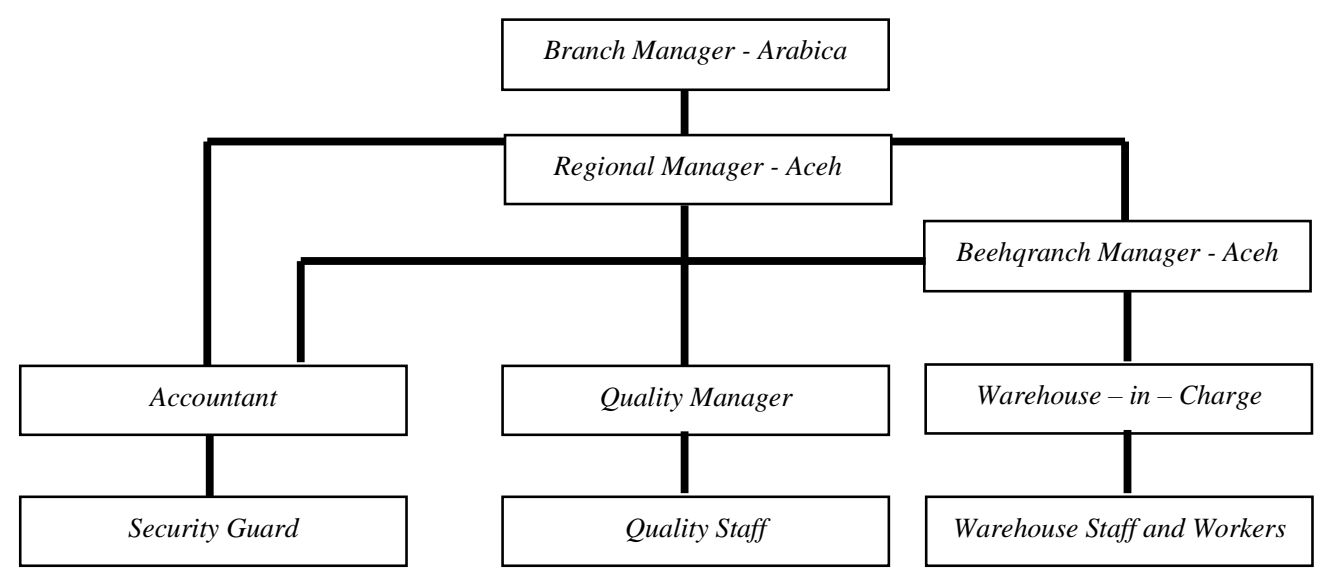

Figure 1 - Organizational Structure of PT. Indo Cafco

In the company PT. Indo Cafco, the highest leader in Indonesia is the Head of Arabica Branch (Arabica Branch Manager), namely Mr. Santosh Kumar who is responsible for all PT. Indo Cafco Arabica. For the Aceh Province is led by the Head of the Aceh Regional (Aceh Regional Manager), namely Mr. Vinod Kumar who is responsible for all procurement, processing and execution of the Aceh branch operations. Then Aceh was led by the Aceh Branch Manager, namely Mr. Zulkifli who was responsible for all branch administrations such as government and environmental management.

The head of the Aceh branch also oversees the performance of the Accounting Staff (Accountant), namely Mr. Muhammad Hanif who is responsible for all company accounting 
activities such as issuing payment checks to suppliers. Quality Staff (Quality Manager) namely Mr. Mahdi Usati who is in charge of coffee quality management assisted by Subali and Mansyah as members. Warehouse worker staff (Warehouse / Production - in - Charge) namely Mr Meryadi who is responsible for workforce control, work allocation and warehouse management, and ensure all workers wear personal protective equipment (PPE)and worker training assisted by Saidi as a Member.

There are several types of coffee processing at PT. Indo Cafco. Natural Process is often called dry process or Dry or Unwashed (not exposed to water / washed). In essence, this process is carried out immediately after the cherry coffee is picked from the tree, then dried in the sun without first peeling it until the water content is around 10 to $13 \%$, drying is carried out for approximately 30 days depending on the conditions of the sun. This method is expected to make the coffee ferment and make the coffee taste more varied, so that it can make the coffee profile stronger and have its own characteristics. Natural specialty coffee processing can be seen in the following scheme.

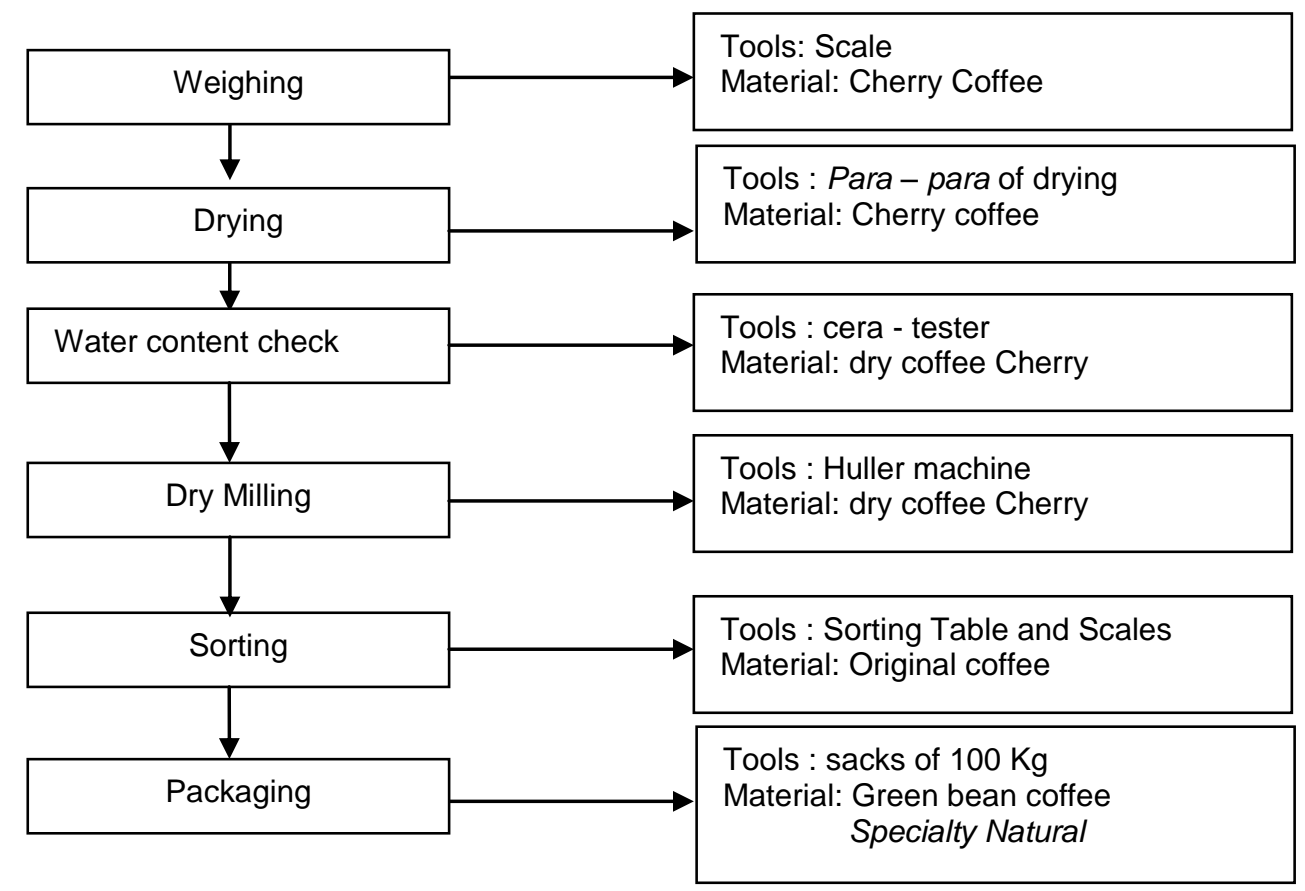

Figure 2 - Processing of Natural Specialty Coffee

Through the picture above, you can see the processing of cherry coffee into Natural Specialty coffee at PT. INDO CAFCO. Namely starting from receiving cherry coffee from farmers which is then weighed using a scale. After that the coffee is immediately taken to the drying, namely para-para who are deliberately made specifically for drying specialty coffee made of wire nets. Cherry coffee is dried in the sun until the moisture content reaches 10 $13 \%$ which is measured using a cera-tester machine, usually if the weather is not raining then the drying is done for 30 days.

If the water content is appropriate, the dry cherry coffee is ground using a dry Huller machine, then the coffee beans that are already in the form of original coffee are sorted on the sorting table using a bucket to separate specialty coffee from non-grade coffee. Specialty coffee is the end result of this process which is also called Natural specialty green bean coffee. Before sending or selling the coffee beans are packed or packed using a bag with a capacity of $100 \mathrm{~kg}$ of coffee beans. Pulp Natural / Honey Process namely coffee dried with mucus without the fermentation process. The stages of the Natural Pulp coffee process are as follows in Figure 3. The difference between the Natural process and Natural Pulp, especially coffee, where natural coffee does not go through the pulping process, while other processes such as dry huller and sorting are the same. 


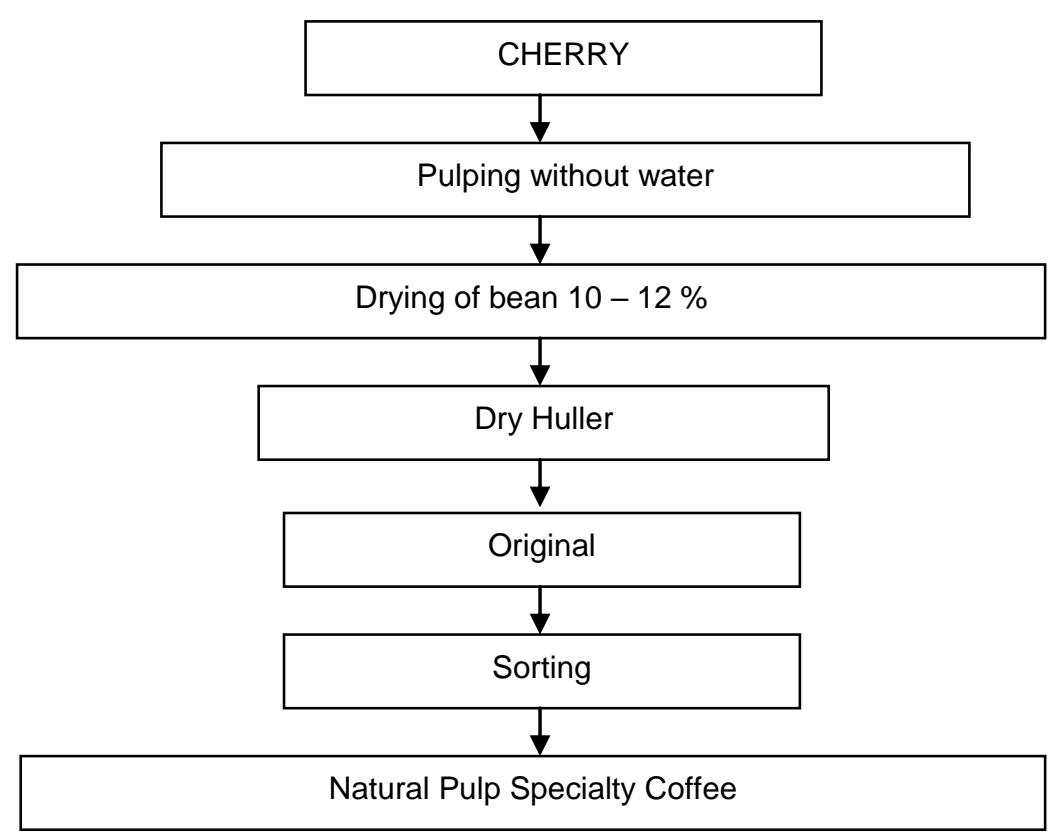

Figure 3 - Stages of the Natural Pulp coffee process

Full Washed namely the processing of coffee with very clean washing (2 times washes). The stages of Full Washed specialty coffee are as follows:

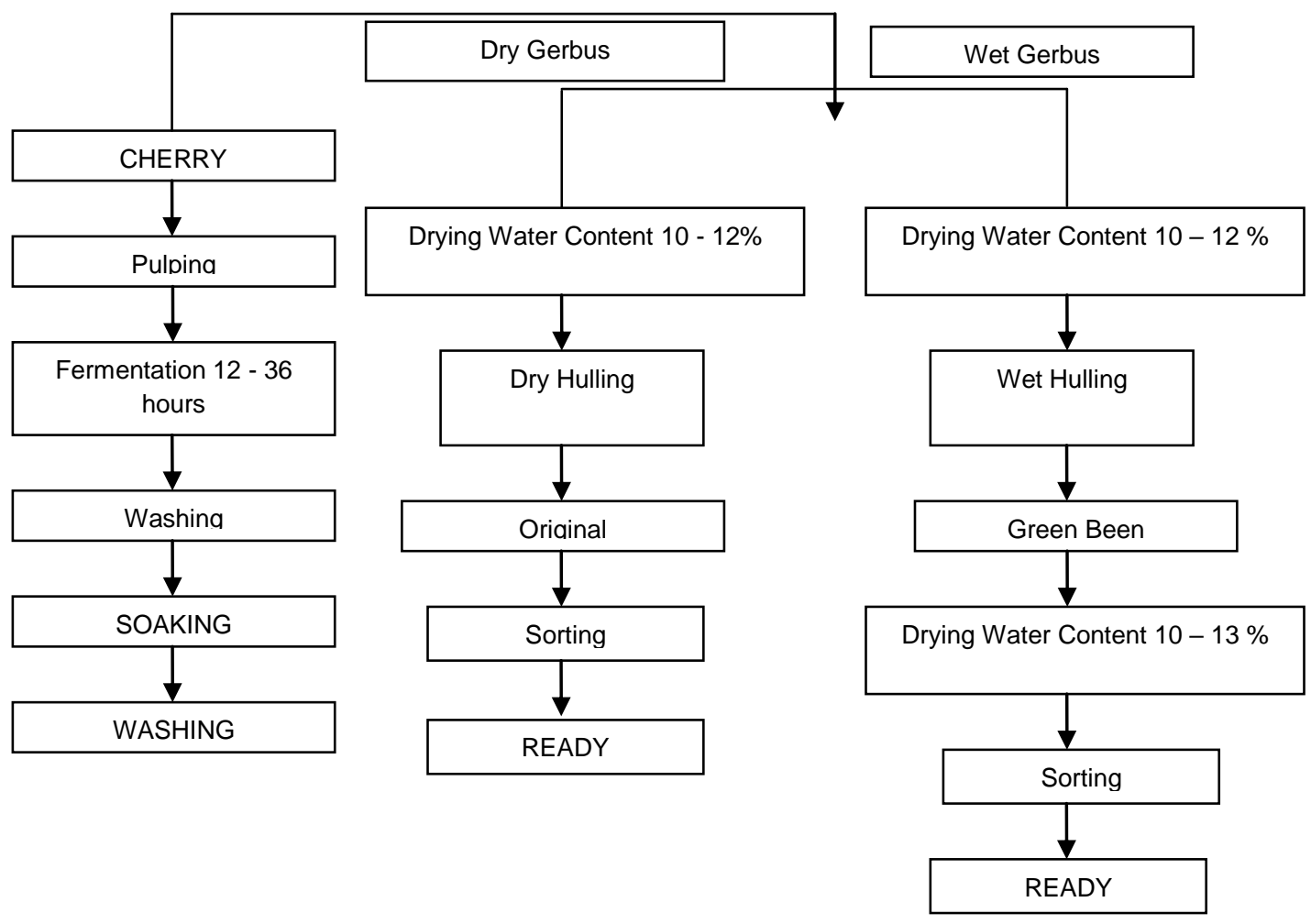

Figure 4 - Full Washed Coffee Process Stages

PT. Indo Cafco processes 3 specialty coffee processes, namely full washed, honey, and natural using the same raw materials, equipment and buildings, but the processes of the three specialty coffees are different. However, in this study, only the natural specialty coffee process is calculated. In this case, costs included in shared costs or used in full washed, 
honey, and natural processing are building rental costs, labor costs, equipment depreciation costs or included in fixed costs.

The calculation of the cost of production is carried out per month, because processing the incoming raw materials takes 30 days to process. So that in calculating production costs based on incoming raw materials or the amount of costs per one time production, namely for 1 month.

Production costs incurred for Natural Specialty Coffee at PT. Indo Cafco is actually always the same, the only difference is the amount of raw material, namely coffee logs (Cherry)come out and the price of raw materials, this is because all of the equipment used in the production process is the same, and the labor that is issued is always the same, namely 1 person who specifically handles the specialty coffee section, and even then the wage given is a fixed monthly wage, because he has become a permanent employee at PT. Indo Cafco.

Fixed costs incurred in processing natural specialty coffee are building rent, depreciation of equipment, taxes and labor: The following is the total fixed costs incurred each month starting from October 2018 - November 2019, for June, July and August 2019 it is not calculated because there are no raw materials, so there is no production process for Natural specialty coffee.

Table 2 - Total fixed costs for processing Natural Specialty Coffee at PT. Indo Cafco

\begin{tabular}{|c|c|c|}
\hline No. & Type of Cost & Total Cost (Rp) / Month / Production process \\
\hline 1 & Building Rental & $833.333,33$ \\
\hline 2 & Depreciation of Equipment & $585.000,00$ \\
\hline 3 & Tax & $50.000,00$ \\
\hline 4 & Labor & $1.500 .000,00$ \\
\hline \multicolumn{2}{|c|}{} & Total Fixed Costs \\
\hline
\end{tabular}

Source: Primary data processed (2019).

That the building lease with a value of $\mathrm{Rp} .833,333.33$, the total depreciation cost of the equipment is Rp. 585,000.00 per month, tax per year with a value of Rp. 50,000. Among the equipment is a small Huller machine that is used for stripping the skin, and the Cera Tester which is a tool to test the moisture content of coffee beans. For more details on fixed costs, see attachment 2.

The labor cost in processing natural specialty coffee is 1 person, who works from 08 : 30 WIB to 17: 30 WIB, who specifically handles specialty coffee with a wage of Rp. $4,430,000.00$ per month.

The variable costs incurred in processing natural specialty coffee are in the form of electricity costs incurred when using the Huller machine and lighting costs, packaging costs in the form of $100 \mathrm{~kg}$ sacks for Rp. 2,000.00 / piece and raw material costs in the form of red log coffee (Red Cherry) The following is the amount of raw materials received by PT. Indo Cafco to be processed into natural specialty coffee.

Table 3 - Variable costs in processing Natural Specialty Coffee at PT. Indo Cafco period September 2018 - October 2019

\begin{tabular}{|c|c|c|c|}
\hline No. & Type of Cost & Total Cost (Rp.) & $\begin{array}{c}\text { Average / Production } \\
\text { (Rp / Production Process) }\end{array}$ \\
\hline 1 & Raw material & $134,769,800$ & 6.417 .610 \\
\hline 2 & Electricity & 15,426 & 7.341 \\
\hline 3 & Packaging & 96,000 & 4.571 \\
\hline & Total & $134,881,226$ & - \\
\hline & Average & 111,426 & - \\
\hline
\end{tabular}

Source: Primary data processed (2019).

The total costs incurred in processing natural specialty coffee are the sum of fixed costs and variable costs, here are the total costs incurred during the period September 2016 to October 2016. 
Table 4 - Biaya Total pengolahan Natural Specialty Coffee di PT. Indo Cafco period September 2018 - October 2019

\begin{tabular}{|c|c|c|c|}
\hline No. & Type of Cost & Total Cost (Rp.) & $\begin{array}{c}\text { Average / Production } \\
\text { (Rp / Production Process) }\end{array}$ \\
\hline 1 & Fixed cost & 2.968 .333 .33 & $2.968 .333,33$ \\
\hline 2 & Variable Costs & $134,881,226$ & $6.429 .522,00$ \\
\hline & Total Costs & $431,714,559$ & - \\
\hline & Average & $9.397 .855,23$ & - \\
\hline
\end{tabular}

Source: Primary data processed (2017).

The selling price of Natural Specialty Coffee is actually determined by PT. Indo Cafco, located at the Medan branch. Even so, the price issued must see the condition of the market price so that consumers do not feel disadvantaged, and the company must look at the cost incurred. The average selling price of natural specialty coffee pumpkins is IDR $139,524 / \mathrm{Kg}$. During the period from September 2018 to October 2019, the change in the selling price of Natural specialty coffee was indeed not too different, it was still in the price range of Rp. $135,000,-/ \mathrm{Kg}$ for the lowest price and Rp. 150,000 / Kg for the highest price that occurred at PT. Indo Cafco. The results of the analysis using SPSS.16 for windows are shown in the following table:

Table 5 - Results of Product Moment Correlation Analysis using SPSS.16 Relationship between Production Costs and Selling Prices

\begin{tabular}{|c|c|c|c|}
\hline \multirow{2}{*}{ Production costs } & $\mathrm{n} / \mathrm{n}$ & Production Costs & Selling Prices \\
\cline { 2 - 4 } & Pearson Correlation Sig (1-tailed) & 1 & .971 \\
\hline \multirow{2}{*}{ Selling price } & $\mathrm{N}$ & 21 & 21 \\
\cline { 2 - 4 } & Pearson Correlation Sig (1-tailed) & $.971^{\prime \prime}$ & 1 \\
\hline
\end{tabular}

Source: Primary data processed (2019).

Product Moment correlation coefficient which shows that the closeness of the relationship between production costs and the selling price of specialty natural coffee at PT. Indo Cafco amounted to $97.1 \%$ (Percent). The correlation between production costs and the selling price of natural specialty coffee at PT. Indo Cafco is positive, which means that the relationship is unidirectional. Called unidirectional if the change in selling price is followed by production costs. If the production cost goes up, the selling price goes up, if the production cost goes down, the selling price will go down too.

Correlation output shows a significance level of 0.00 . Because the significance level of the correlation coefficient is above 0.05 with a positive coefficient of direction, the correlation between production costs and selling prices is stated to be significantly positive.

To test the significance of the correlation, the following test criteria are used:

- Comparing $r$ table with $r$ count. Based on the calculation results, the Product Moment correlation coefficient is 0.971 . While the value of $r$ table with of $(\alpha, n-2)$ or $(0.05,19)$ obtained $r$ table value of 0.632 . Because the calculated $r$ value $>$ the $r$ table value, it can be concluded that there is a positive correlation between production costs and selling prices.

- Comparing $t$ table with $t$ count. To find out the value of $t$ table for the correlation coefficient that has been obtained, the calculated $r$ value is transformed as follows:

$$
\mathrm{t}=\frac{\mathrm{r} \sqrt{\mathrm{n}-2}}{\sqrt{1-\mathrm{r}^{2}}}
$$

- Based on the results of the above calculations, the $t$ value is 17.707 , while the $t$ table value with df $(\alpha, n-2)$ or $(0.05,19)$ is obtained by the table value of 2.228 . Because 
the $t$ value (17.7070> $t$ table value (2.228), it can be concluded that there is a positive correlation between production costs and selling prices.

- Comparing the Sig. With $\alpha$. Correlation output shows a significance level of 0.000 below 0.05 with a positive coefficient of direction. So the correlation between production costs and selling prices is stated as a positive significance.

- The closeness of the relationship between production costs and selling prices can be seen in the correlation coefficient of 0.971 , which means that the correlation is very strong. In accordance with the correlation coefficient criteria where if the correlation coefficient value is 0.80 to 1.00 , the correlation is very strong.

The closeness of the relationship between the cost of production and the selling price is also shown in the following curve:

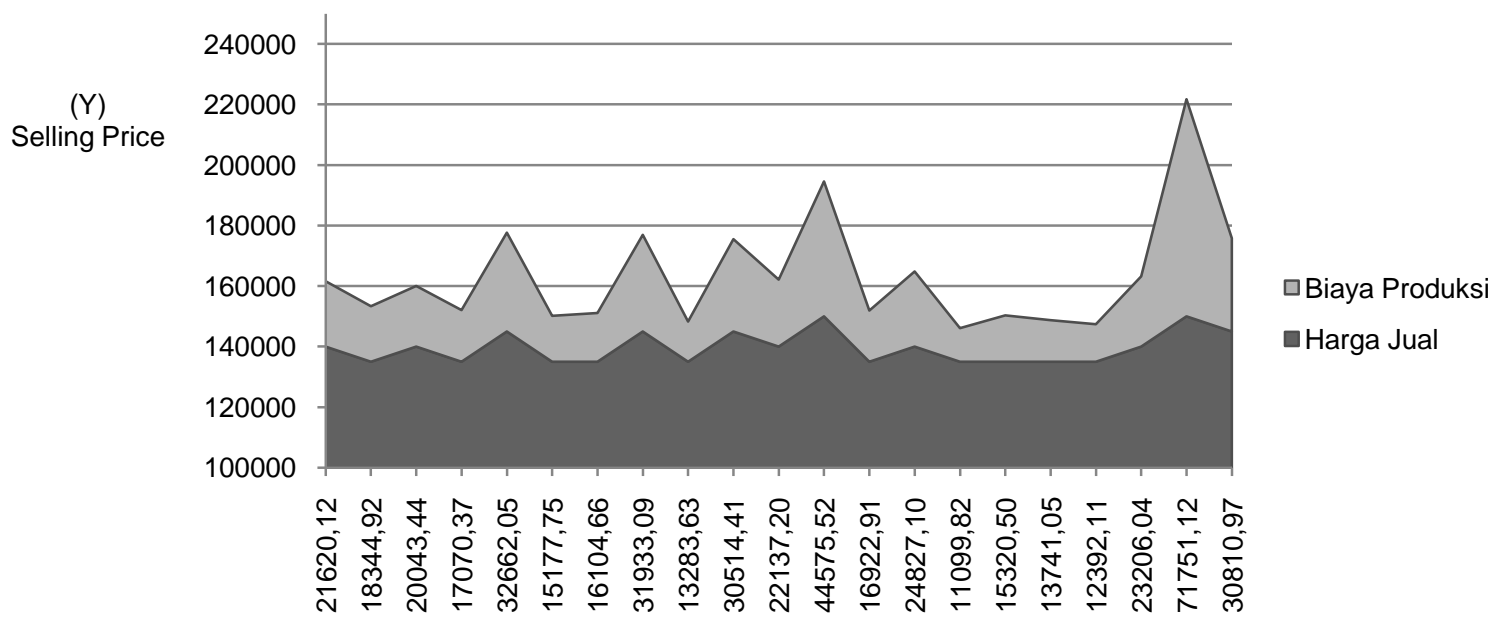

Figure 5 - The curve of the correlation between production costs and the selling price of natural specialty coffee at PT. Indo Cafco

From the curve above, it can be seen that every change that occurs in production costs must be followed by changes in selling prices, both increase and decrease. However, the changes that occur between production costs and selling prices are not the same, this is because changes in the selling price are still stable, ranging from Rp. 135,000.00 to Rp. $150,000.00$. Meanwhile, changes in production costs are not very stable, such as in the 19th production, the production cost is Rp. 23,206.12 which then in the 20th production line increases sharply because the production cost rises to Rp. 71,751.12.

Internal factors, namely the marketing objectives of course PT. Indo Cafco wants to get maximum profit so that the company can continue to run but can still maintain the quality of its products in order to overcome competition. Other internal factors in determining the selling price at PT. Indo Cafco is an organization, which is determined by PT. Indo Cafco, which is located in a branch in Central Aceh, does not yet exist. Even though it is Medan, because for the sales manager who is like this, what must be considered in determining the selling price is the production cost which determines the lowest selling price that can be issued so that the company does not experience losses.

The external factors that affect the selling price are market demand and market competition. In this case, the demand for Natural Specialty Coffee products is still quite high, even PT. Indo Cafco is still experiencing limitations in production because the amount of raw materials available is still small. Meanwhile, the market competition itself is quite large, because in the Central Aceh area, there are already many coffee bean processing companies that also provide specialty coffee products, so that in determining the selling price of Natural Specialty Coffee, Natural Specialty Coffee also looks at the selling price of competitors. 
Other external factors in the form of product differentiation have actually been carried out by coffee bean processing companies in Central Aceh, including PT. Indo Cafco, as in the form of packaging, product descriptions such as processing and origin of the raw materials used, so that companies can change their selling price based on the product description.

From external factors point of view, the ease of entering the industry, in fact Natural coffee bean processing is a product that is difficult to enter when viewed from the technological requirements, availability of capital and raw materials which are still limited at this time. Therefore, not many coffee bean processing industries process natural specialty coffee, so there are still few who control the selling price of natural specialty coffee in the market.

\section{CONCLUSION AND RECOMMENDATIONS}

The amount of production of natural specialty coffee from September 2018 to October 2019 is $3,707 \mathrm{~kg}$ with an average production rate of $176.5 \mathrm{~kg}$. The total cost for processing raw materials of $12,545.9 \mathrm{~kg}$ is Rp. $197,354,959.93$, with an average cost per kilogram of Rp. 23,978.04.The average selling price of natural specialty coffee at PT. Indo Cafco is Rp. $139,524,-$.

The Product Moment correlation coefficient value is 0.971 , which means that the closeness of the relationship between production costs and selling prices is $97.1 \%$ and is unidirectional. Output Correlation indicates a significance level of 0.000 . Because the significance level of the correlation coefficient is below 0.05 with a positive coefficient direction, the correlation between production costs and selling prices is stated to be significantly positive.

Recommendations:

- Farmers are expected to sell Red Cherry coffee, which is completely red, so that the production of natural specialty coffee can be increased.

- PT. Indo Cafco can increase the price of natural specialty coffee by taking into account the production costs incurred.

- Further researchers, it is hoped to take study in the factors that influence the selling price of natural specialty coffee at PT. Indo Cafco or at other places / locations in Aceh Tengah District

\section{REFERENCES}

1. Anonimous (2009). Persyaratan Kopi Arabika Versi Rinci. Masyarakat Perlindungan Kopi Gayo MPKG, Takengon.

2. Assuari 2008.Manajemen Produksi dan Operasi. Lembaga Penerbit Fakultas Ekonomi Universitas Indonesia: Jakarta.

3. Fitri.llma, Gunawan (2020)Analisis Nilai Tambah Pengolahan Kopi Dengan Metode Wet Process - Wet Hulling Di Asa Coffee Kecamatan Bebesen Kabupaten Aceh Tengah. Jurnal Hexagro 4 No 1. Februari 2020 39-54.

4. Haryanto,B. 2012. Prospek Tinggi Bertanam Kopi. Pustaka Baru Press, Yogyakarta.

5. Hernanto, F. 2007.Ilmu Usahatani. Penebar Swadaya: Jakarta.

6. Kementan.2012. Statistik Pertanian 2011 (Agricultural Statistics).Pusat Data dan Sistem Informasi Pertanian. Kementerian Pertanian.

7. Kuswadi.2005. Meningkatkan Laba Melalui Pendekatan Akuntansi Keuangan dan Akuntansi Biaya. PT. Elex Media Komputindo, Jakarta.

8. Manurung, M. dkk (2012). Buku Paduan Upaya Peningkatan Produksi dan Kualitas Kopi Arabika Gayo Yang Berkelanjutan. Takengon.

9. Miftah.2014. Pasca Panen. Majalah otten, Jakarta.

10. Mulyadi. 2005. Akuntansi Biaya,edisi ke-6. Yogyakarta: STIE YKPN.

11. Mulyadi, (2007) Akuntansi Biaya Edisi 5. Universitas Gajah Mada: Yogyakarta.

12. Samuelson. 2003. Ilmu Mikro Ekonomi.PT Media Globa Edukasi, Jakarta. 
13. Sukirno, S. 2004.Makro Ekonomi Teori Pengantar.PT Raja Grafindo Perkasa. Jakarta.

14. Suwarto, dkk (1997). Ekonomi Untuk SMU Kelas 1. Grafindo Media Pratama. Jakarta.

15. Sugiyono. 1999. Metode penelitian bisnis. CV Alfabeta. Bandung.

16. Suratiyah. 2006. Ilmu Usahatani. Penebar Swadaya. Jakarta.

17. Sotriono, dkk. 2006. Pengantar Ilmu Pertanian Agraris, Agrobisnis, dan Industri. Bayumedia Publishing. Malang.

18. Soekartawi, 2002, Prinsip Dasar Manajemen Pemasaran Hasil- Hasil Pertanian Teori dan Aplikasinya, Raja Grafindo Persada: Jakarta.

19. Yantu, M. R. 2010. Integrasi pasar t4r3fWGE3gy\%rEnj kopi gayo dengan pasar dunia. Jurnal Agro Ekonomi 28 (2): 201-225. 